\title{
Virtual Confrontation: Is Videoconference Testimony by an Unavailable Witness Constitutional?
}

\author{
Matthew J. Tokson†
}

\section{INTRODUCTION}

As business and commerce become more international in scope, related crimes such as fraud, ${ }^{1}$ money laundering, ${ }^{2}$ drug trafficking, ${ }^{3}$ violation of trade sanctions, ${ }^{4}$ and even antitrust violations ${ }^{5}$ are increasingly likely to involve international commerce. ${ }^{6}$ In such cases, it is probable that a prosecutor will require testimony from foreign witnesses to prove his or her case. ${ }^{7}$ Federal prosecutions of suspected terrorists, which may become more frequent in the coming decade, are also likely to involve foreign witnesses residing overseas.

Securing the testimony of such witnesses may present prosecutors with serious difficulties. The United States and its federal courts have no subpoena power over foreign nationals residing in a foreign country, ${ }^{8}$ and therefore prosecutors and judges cannot compel foreign witnesses to travel to the United States to appear at trial. There may, in some cases, be a treaty between the United States and the foreign country that allows prosecutors to use the foreign government's power to compel witnesses to testify via deposition in their own nations. ' Still, the only way to secure a foreign witness for testimony at the trial itself is to convince the witness to voluntarily make the journey to the United States. If the witness is unwilling to travel, he is essentially unavailable ${ }^{10}$ to testify at trial.

\footnotetext{
AB 2002, Dartmouth College; JD Candidate 2008, The University of Chicago.

See, for example, United States v Drogoul, 1 F3d 1546, 1549 (11th Cir 1993).

See, for example, United States v Sturman, 951 F2d 1466, 1471-72 (6th Cir 1991).

See, for example, United States v Salim, 855 F2d 944, 947-48 (2d Cir 1988).

See, for example, United States v McKeeve, 131 F3d 1, 5-7 (1st Cir 1997).

See, for example, United States v Nippon Paper Industries Co,17F Supp 2d 38,39 (D Mass 1998).

6 See Lynn Helland, Remote Testimony-A Prosecutor's Perspective, 35 Mich J L Reform

7 See id at 724 . See also cases cited in notes $1-5$.

8 United States v Filippi, 918 F2d 244, 246 n 2 (1st Cir 1990) (stating that US statutes only provide for serving subpoenas on US nationals or residents located in foreign countries, and do not provide for subpoenas of foreign nationals located abroad). See also the Walsh Act, 28 USC $\$ 1783$ (2000) (providing that courts may issue subpoenas directed towards US nationals or

9 See Helland, 35 Mich J L Reform at 724 (cited in note 6).

10 See note 160 for a discussion of the legal meanings of unavailability.
} $719,723-24$ (2002). residents in foreign countries). 
Videoconferencing technology, already frequently used by businesses and law firms conducting national and international transactions, offers a potential way around these difficulties. Foreign witnesses may be willing to testify before the court via the less burdensome method of satellite video transmission even when they are unwilling to travel to the United States to testify."

In several recent cases, a federal or state government prosecutor has requested permission to introduce testimony by foreign (or otherwise unavailable) witnesses via satellite video transmission, and trial judges have generally granted such permission. ${ }^{12}$ However, defendants have often challenged the use of such testimony on constitutional grounds, arguing that the use of video testimony in court violates their Sixth Amendment right to confront the witnesses testifying against them.

The Confrontation Clause of the Sixth Amendment provides: "In all criminal prosecutions, the accused shall enjoy the right ... to be confronted with the witnesses against him." ${ }^{13}$ The Supreme Court has held that Sixth Amendment confrontation need not always be in person. The Court, in Maryland $v$ Craig, ${ }^{i 4}$ ruled that child witnesses accusing a defendant of molestation can testify via videoconference without violating the Confrontation Clause when the trial court makes a specific finding that the child would be otherwise unable to communicate

11 See Helland, 35 Mich J L Reform at 725 (cited in note 6) (describing the author's personal experience with foreign witnesses willing to accommodate requests not involving travel).

12 See, for example, United States $v$ Yates, 438 F3d 1307, 1310 (11th Cir 2006) (en banc); Nippon Paper, 17 F Supp 2d at 42-43; Harrell v State, 689 S2d 400, 402 (Fla Ct App 1997). Though the issue is largely beyond the scope of this Comment, note that the procedural basis for allowing such testimony has not been firmly established. A judge dealing with the similar situation of proffered video testimony from a seriously ill (and thus unavailable) domestic witness allowed a video conference upon the basis of his "inherent power" under FRCrP 2 and 57(b) to "structure a criminal trial in a just manner." See United States v Gigante, 166 F3d 75, 80 (2d Cir 1999). A firmer basis for the admission of such testimony is simply treating it as though it were testimony given in court (despite the lack of physical presence). See Harrell, 689 S2d at 402. Thus, it can be argued that video testimony comports with the language of FRCrP 26 ("[T]he testimony of witnesses must be taken in open court, unless otherwise provided by a statute or by rules.") and is permissible. See Brief for the United States on Rehearing En Banc, United States $v$ Yates, No 02-13654, *18-20 (11th Cir filed Aug 11, 2005) ("Prosecutor's Yates Brief"). See also Official Airline Guides, Inc v Churchfield Publications, Inc, 756 F Supp 1393, 1398-99 n 2 (D Or 1990) (characterizing testimony via teleconference as made "in open court"). In any event, courts have not focused on this issue in cases disputing the use of video testimony, and apparently no court has interpreted Rule 26 in light of video testimony. See Prosecutor's Yates Brief at *17-18. Nor does the rejection of an amendment to Rule 26 that would have expressly permitted the use of videoconference testimony necessarily indicate that no authority currently exists under the Federal Rules. Consider United States $v$ Wise, 370 US 405, 411 (1962) (finding that the failure of an amendment expressly providing that corporate officers could be found liable under the Sherman Act did not indicate that officers were exempt under the existing statute and emphasizing the possibility that "the existing legislation already incorporated the offered change").

13 US Const Amend VI.

14497 US 836 (1990). 
due to serious emotional distress caused by the presence of the defendant. ${ }^{15}$ Under the test established in Craig, a defendant's rights under the Confrontation Clause are not violated despite the absence of an in-person confrontation at trial where "denial of such confrontation is necessary to further an important public policy and [ ] where the reliability of the testimony is otherwise assured." ${ }^{16}$

However, the constitutionality of videoconference testimony given by unavailable adult witnesses against criminal defendants is still unsettled, and the two circuit courts to consider the issue have split. The Second Circuit declined to apply the Craig test and found video testimony constitutional because it was reliable and preserved all of the constitutionally required elements of in-court testimony. ${ }^{17}$ The Eleventh Circuit, by contrast, applied the Craig test and held that videoconferencing did not further an important public policy and was not a constitutionally acceptable alternative because the prosecution could have deposed the unavailable witness in the presence of the defendant under FRCrP $15 .^{18}$

This Comment attempts to resolve this circuit split by arguing that the Craig test should apply to videoconference testimony but that the test should be leniently applied in the context of video testimony by unavailable witnesses. It further argues that such testimony serves important public policies, and thus passes the Craig test, in a wide variety of situations.

Part I examines the text, purpose, and historical background of the Confrontation Clause and elucidates the central elements of the confrontation right. Part II examines Craig and other cases dealing with exceptions to the Confrontation Clause's general preference for face-to-face, physical confrontation at trial. Part III details the circuit split over the constitutionality of video testimony and analyzes the arguments on both sides.

Part IV concludes that, based upon the Supreme Court's Confrontation Clause doctrine, the Craig test should be applied to video testimony. It also concludes that video testimony often produces better evidence at trial and frequently provides better protection of the central elements of the confrontation right than do FRCrP 15 deposi-

15 Id at $857-60$.

16 Id at 850 . Note that Craig's reliability prong is not really at issue in most cases involving video testimony from foreign witnesses. Such testimony is subject to cross-examination, allows the judge and jury to view the demeanor of the witness, and typically occurs under oath. See id at 851-52 (finding that video testimony was constitutionally reliable and stating that the critical inquiry was whether it was "necessary to further an important state interest").

17 See Gigante, 166 F3d at 80-82.

18 See Yates, 438 F3d at 1312-18. 
tions. In light of these advantages, Part IV proposes that courts apply the Craig test leniently to video testimony and describes several factual situations in which courts can allow video testimony without violating the doctrinal framework established in Craig.

\section{THE CONFRONTATION CLAUSE}

As the Supreme Court has recently acknowledged, the text of the Confrontation Clause ${ }^{19}$ is ambiguous as to whether the confrontation requirement for "witnesses against" applies to only those witnesses who actually testify at trial, all witnesses whose out-of-court statements are offered at trial, or something in between. ${ }^{20}$ In interpreting the clause, the Court has generally opted for "something in between," routinely holding that prior hearsay testimony can be admitted against a defendant without violating the Confrontation Clause-but only so long as the witness is unavailable and the defendant has had a prior opportunity to cross-examine. ${ }^{21}$

With respect to witnesses testifying before a jury during trial, the text is also unclear as to whether actual physical confrontation is required to satisfy the "to be confronted" requirement. Supreme Court precedent offers conflicting interpretations. The Court has said that the clause guarantees a "face-to-face" meeting with such witnesses. ${ }^{22}$ It is unclear from Supreme Court precedent whether video testimony would satisfy the "face-to-face" requirement or whether "face-to-face" requires physical presence. ${ }^{23}$ Additionally, the Court has held that the

19 "In all criminal prosecutions, the accused shall enjoy the right ... to be confronted with the witnesses against him." US Const Amend VI.

20 See Crawford $v$ Washington, 541 US 36, 42-43 (2004).

21 See id at 61, 68; Ohio v Roberts, 448 US 56, 63-66, 73 (1980), overruled in part by Crawford, 541 US at 67-68. See also United States $v$ Yates, 438 F3d 1307, 1329-30 (11th Cir 2006) (Marcus dissenting) (discussing previous cases applying a nonliteral standard to the prior testimony of unavailable witnesses); Part II.A (describing the historical development of Confrontation Clause jurisprudence). As the Supreme Court has noted, a nonliteral approach is necessary because "a literal interpretation of the Confrontation Clause could bar the use of any out-ofcourt statements when the declarant is unavailable," a view that is "unintended and too extreme." Bourjaily v United States, 483 US 171, 182 (1987).

22 Coy v lowa, 487 US 1012, 1016 (1988). See also the discussion in Part II.A.

23 Most circuit courts have found that "face-to-face" means actual physical confrontation of the witness. Compare Yates, 438 F3d at 1313-14 (treating physical confrontation as necessary to satisfy the face-to-face requirement); United States $v$ Turning Bear, 357 F3d 730, 736 (8th Cir 2004) (same); United States v Moses, 137 F3d 894, 897 (6th Cir 1998) (same); United States $v$ Quintero, 21 F3d 885, 892 (9th Cir 1994) (same), with United States v Gigante, 166 F3d 75, 81 (2d Cir 1999) (holding that two-way video conferencing that allows the witness and the defendant to see each other satisfies the face-to-face requirement). Given the Supreme Court's enumeration of the virtues of physical confrontation in Coy, 487 US at 1019-20 ("It is always more difficult to tell a lie about a person to his face than behind his back.") (quotation marks omitted), it is likely that the Court would side with the majority on this issue. Of course, as this Comment argues, video testimony may fit into one of the exceptions the Court has found to the face-to-face rule. 
clause does not require in-person confrontation with witnesses in all circumstances, suggesting that physical presence is not a crucial part of the constitutional right to confront. ${ }^{24}$ Given the ambiguity in the meaning of the Confrontation Clause, it is useful to look at the history of the clause in order to discern its central purposes and to reach a meaningful definition of the confrontation right.

\section{A. History of the Confrontation Clause}

There is virtually no traditional legislative history on the Sixth Amendment's Confrontation Clause. ${ }^{26}$ The clause was included without floor debate within the Sixth Amendment's package of rights, "all incidents of the adversarial proceeding before a jury as evolved during the 17th and 18th centuries." ${ }^{27}$ Despite the lack of legislative history, the Supreme Court has often looked to the historical context of the Confrontation Clause's adoption when interpreting the clause, most recently and thoroughly in Crawford $v$ Washington.

The Crawford Court looked first to English legal practice regarding witnesses in criminal cases. While English common law generally required live testimony in court subject to cross-examination, procedures borrowed from continental civil law practice allowed court officials to examine witnesses before trial outside the presence of the defendant, and the transcripts were sometimes used at trial. ${ }^{29}$ Statutes passed during the reign of Queen Mary expanded the use of such transcripts at trial. ${ }^{30}$ The most infamous example was the trial of Sir Walter Raleigh, where the out-of-court testimony, likely coerced by torture, of Raleigh's alleged accomplice in a treason plot was used to sentence Raleigh to death. ${ }^{31}$

The English system eventually developed a right of confrontation, focused largely on the right to cross-examine, in response to

24 See Craig, 497 US at 849-50.

25 See Crawford, 541 US at 43 ("We must therefore turn to the historical background of the Clause to understand its meaning.").

26 See California v Green, 399 US 149, 176 n 8 (1970) (Harlan concurring) ("[T]he usual primary sources and digests of the early debates contain no informative material on the confrontation right."). See also Maria H. Bainor, Note, The Constitutionality of the Use of Two-Way Closed Circuit Television to Take Testimony of Child Victims of Sex Crimes, 53 Fordham L Rev 995,1005 n 51 (1985) ("[T]here is no available legislative history on the confrontation clause.").

27 Green, 399 US at 175-76 (Harlan concurring).

28541 US 36, 43-50 (2004).

29 Id at 43 (noting that the prisoners often demanded to have their accusers brought before them in these situations - and were often refused).

30 Id at $43-44$.

31 Id at 44 . See also Green, 399 US at 157 n 10 (crediting the theory that the Raleigh case engendered the Confrontation Clause). 
these abuses. ${ }^{32}$ A similar process occurred around the time of colonial independence, as several states adopted declarations of rights including a right to confront prosecution witnesses in criminal trials. ${ }^{33}$

Though the Constitution as originally drafted did not include a confrontation right, the First Congress included one in the Sixth Amendment. ${ }^{34}$ Early state cases interpreted the confrontation right to include the right to cross-examine an adverse witness testifying at trial and the right to cross-examine adverse witnesses during depositions to be used at trial. ${ }^{35}$ Based on its historical analysis, the Crawford Court endorsed the relatively uncontroversial historical conclusion reached in California v Green $^{36}$ and other Supreme Court cases: ${ }^{37}$ the First Congress of the United States included the Confrontation Clause in the Sixth Amendment in response to concerns about the use of $e x$ parte (from one party only) written testimony in trials against criminal defendants who were given no opportunity to cross-examine or otherwise confront their accusers. ${ }^{38}$ The Crawford Court therefore reaffirmed that the Confrontation Clause applies to both in-court and outof-court testimony.

\section{B. The Supreme Court's Interpretation of the Purposes of the Confrontation Clause}

Based on the historical context of the Confrontation Clause's adoption as described in Crawford, Green, and other cases, the Supreme Court has drawn a number of conclusions about the general purposes of the Confrontation Clause. These conclusions suggest that actual physical confrontation is not an essential part of the Framers' conception of the confrontation right. The historical purpose of the clause (avoiding conviction of defendants based on unreliable written affidavits) suggests that the purpose of the clause is largely functional rather than formal. Accordingly, the Court has repeatedly endorsed

32 Crawford, 541 US at $44-47$.

33 See id at 48 (explaining that Virginia, Pennsylvania, Delaware, Maryland, North Carolina, Vermont, Massachusetts, and New Hampshire adopted rights of confrontation between 1776 and 1783).

34 Id at $48-49$.

35 Id at $49-50$.

36399 US 149 (1970).

37 See, for example, Mattox v United States, 156 US 237, 243 (1895).

38 See Crawford, 541 US at 50.

39 See id at 50-51 ("Leaving the regulation of out-of-court statements to the law of evidence would render the Confrontation Clause powerless."). Note that duierent constitutional standards are generally applied to the two different kinds of testimony. See White $v$ Illinois, 502 US 346, 358 (1992) (distinguishing the constitutional analyses of the confrontation right in cases where the witness is available from those where the witness is unavailable and the testimony is out-of-court hearsay). See also notes $49-50$ and accompanying text. 
the concept that "the right to confrontation is a functional one for the purpose of promoting reliability in a criminal trial."

The Court has found that the purposes of the Confrontation Clause are clearly served where the classic elements of the confrontation right are present. According to $\mathrm{Craig}$, these include physical presence, testimony under oath, the right to cross-examine the witness, and observation of the witness's demeanor by the trier of fact. ${ }^{41}$ However, as Craig itself suggests, physical presence may not be a necessary element of the confrontation right. Some previous cases have also suggested that oath, cross-examination by defense counsel, and assessment by a trier of fact provide "all that the Sixth Amendment demands: 'substantial compliance with the purposes behind the confrontation requirement." ${ }^{42}$ Indeed, physical presence can be seen as a guarantor of these essential purposes of the Confrontation Clause right, rather than "the sine qua non" of the right."

Furthermore, Crawford suggests that cross-examination is the primary and central element of the confrontation right. According to Crawford, the Confrontation Clause generally reflects the right of confrontation at common law at the time of the passage of the Sixth Amendment. ${ }^{4}$ At that time, the common law "conditioned admissibility of an absent witness's examination on unavailability and a prior opportunity to cross-examine." ${ }^{45}$ The opportunity to cross-examine a prior testimonial statement was "dispositive" as to the confrontation

40 Kentucky v Stincer, 482 US 730, 739 (1987). See also Craig, 497 US at 845 ("The central concern of the Confrontation Clause is to ensure the reliability of the evidence against a criminal defendant by subjecting it to rigorous testing in the context of an adversary proceeding before the trier of fact."); Lee $v$ Illinois, 476 US 530, 540 (1986) ("The right to confront and to crossexamine witnesses is primarily a functional right that promotes reliability in criminal trials."); Dutton v Evans, 400 US 74, 89 (1970) (plurality) ("[T]he mission of the Confrontation Clause is to advance a practical concern for the accuracy of the truth-determining process in criminal trials by assuring that 'the trier of fact [has] a satisfactory basis for evaluating the truth of the prior statement."') (second alteration in original), quoting Green, 399 US at 161.

41 See 497 US at 845-46 (suggesting that these elements ensure that "evidence admitted against the accused is reliable and subject to the rigorous adversarial testing that is the norm of Anglo-American criminal proceedings"), quoting Green, 399 US at 158.

42 Roberts, 448 US at 69, quoting Green, 399 US at 166. Justice Blackmun characterized the language from Green as controlling and relied upon it in holding that the admission of testimony given at a preliminary hearing was constitutional where the defendant had previously crossexamined the witness. See Roberts, 448 US at $69-73$, overruled in part on other grounds by Crawford, 541 US at $67-68$.

43 Craig, 497 US at 847 . Note that before the Supreme Court had to decide whether a child witness could testify behind a screen or via one-way closed-circuit television, there was likely little reason to contemplaie in-court testimony that did not involve physical confrontation. As the Court was faced with these cases, its doctrine evolved to recognize that the essential purposes of the Confrontation Clause could be served, in some circumstances, without actual physical confrontation.

44 See 541 US at 54.

45 Id. 
right question. ${ }^{46}$ Of course, cross-examination at the time of the Sixth Amendment's adoption likely entailed an opportunity for the defendant's physical presence during cross-examination, and Crawford does not address the issue of cross-examination in the absence of physical confrontation. However, it is noteworthy that cases prior to Crawford have endorsed the centrality of cross-examination to the confrontation right even where the defendant does not physically confront the witness. As the Court stated (albeit in dicta) in Douglas $v$ Alabama, "[o]ur cases construing the [Confrontation Clause] hold that a primary interest secured by it is the right of cross-examination; an adequate opportunity for cross-examination may satisfy the clause even in the absence of physical confrontation." examine potential exceptions to the requirement of physical confrontation in greater detail.

\section{CRAIG AND EXCEPTIONS TO THE REQUIREMENT OF PHYSICAL CONFRONTATION FOR WITNESSES TESTIFYING IN COURT}

Courts employ different constitutional standards for available witnesses than for unavailable witnesses. When a witness is available for incourt testimony, courts have been reluctant to deny physical confrontation to the defendant, even when the witness is a child who was allegedly molested by the defendant. ${ }^{49}$ When a witness is unavailable and the prosecutor seeks to admit prior hearsay testimony, the standard is far less stringent and many courts have held that cross-examination during the prior testimony (regardless of physical confrontation) will suffice to render its admission constitutional. ${ }^{50}$ The cases dealing with the requirement of physical confrontation and its exceptions provide the

46 Id at $55-56$.

47380 US 415 (1965).

48 Id at 418-19. See also Delaware v Fensterer, 474 US 15, 22 (1985) ("[T]he Confrontation Clause is generally satisfied when the defense is given a full and fair opportunity to probe and expose these infirmities through cross-examination, thereby calling to the attention of the factfinder the reasons for giving scant weight to the witness's testimony.").

49 See, for example, United States v Turning Bear, 357 F3d 730, 735-37 (8th Cir 2004); United States v Moses, 137 F3d 894, 897-99 (6th Cir 1998).

50 See, for example, United States $v$ Williams, 116 Fed Appx 890, 891 (9th Cir 2004) (holding that the admission of deposition testimony against the defendant when the defendant had not physically confronted the witness at the deposition but was able to cross-examine through counsel did not violate the Confrontation Clause); United States v Medjuck, 156 F3d 916, 920 (9th Cir 1998) (same). Several courts have even held that depositions taken by foreign magistrates without the defendant's presence are constitutionally admissible against defendants in criminal trials. See United States v McKeeve, 131 F3d 1, 10 (1st Cir 1997); United States v Kelly, 892 F2d 255, 260-63 (3d Cir 1989); United States v Salim, 855 F2d 944, 954-55 (2d Cir 1988). See also note 176 and accompanying text. 
relevant doctrinal framework for this Comment's analysis of the constitutionality of video testimony by foreign witnesses.

\section{A. Physical Confrontation and Available Witnesses}

Often in criminal prosecutions for child molestation, the prosecution offers the child's testimony but seeks to minimize trauma to the child by isolating the child behind a screen ${ }^{51}$ or transmitting the testimony by closed-circuit television ${ }^{52}$ so that the child will not have to be in the presence of the defendant. In these cases, the Court has developed a sometimes-contradictory set of doctrines for determining the necessity of physical confrontation and the availability of exceptions to such confrontation under the Sixth Amendment. In Coy $v$ Iowa, the trial court had approved the use of a large screen to be placed between the defendant and two child witnesses testifying that he sexually assaulted them. ${ }^{54}$ The Supreme Court held that the use of the screen violated the defendant's confrontation right: "We have never doubted ... that the Confrontation Clause guarantees the defendant a face-to-face meeting with witnesses appearing before the trier of fact." The Court emphasized the functional value of physical confrontation, arguing that a witness will likely have a more difficult time lying about a defendant if he has to look in the defendant's face and be in the defendant's presence. ${ }^{56}$ The majority did, however, acknowledge that exceptions might exist if they were necessary to further an important public policy."

In Maryland $v$ Craig, the Court established an exception along these lines to the general rule favoring physical confrontation of available witnesses. ${ }^{58}$ The trial court had allowed a child witness to testify via one-way, closed-circuit television against a defendant accused of sexual assault. ${ }^{59}$ As required by the Maryland statute permitting such testimony, the trial court made a finding that the child would

\footnotetext{
1 See, for example, Caban v Tillery, 1998 US Dist LEXIS 8392, *6 (D Kan).

See, for example, Craig, 497 US at 842-43.

487 US 1012 (1988).

See id at 1014-15.

Id at 1016.

56 See id at 1020 "The State can hardly gainsay the profound effect upon a witness of
} standing in the presence of the person the witness accuses.").

57 See id at 1021. See also id at 1024 (O'Connor concurring) (emphasizing that the physical requirement is not absolute and that exceptions may exist where necessity dictates).

58 See Craig, 497 US at 857-60.

59 See id at $841-42$ (explaining that the child witness testified from a separate room, joined by the prosecutor and defense counsel, while the judge, jury, and defendant remained in the courtroom). With one-way video testimony, unlike the two-way videoconferencing that foreign witnesses would use, the defendant could see the witness but the witness could not see the defendant. 
suffer such emotional distress as to be unable to communicate if she were forced to testify in court against the witness. ${ }^{60}$

Though the Maryland Court of Appeals reversed, the Supreme Court vacated the reversal and remanded, holding that the video testimony might be allowed without violating the Confrontation Clause because the clause did not guarantee actual in-person confrontation of a witness in all situations. ${ }^{61}$ The Court pointed to its cases interpreting other Sixth Amendment rights (such as the right to be present at trial and the right to compulsory process of witnesses) in light of the necessities of the trial process, rather than literally.

Though the right to physical confrontation of available witnesses was not "indispensable," the Court emphasized that it was important and that exceptions could be made only in certain circumstances. ${ }^{63}$ Building upon its language in Coy, the Court established what is now known as the "Craig test" for exceptions to in-person, physical confrontation: the absence of such confrontation is permitted "only where denial of such confrontation is necessary to further an important public policy and only where the reliability of the testimony is otherwise assured." ${ }^{, 4}$

Applying this test, the Court found that the procedure at issue (though it prevented the witness from seeing the defendant) was assuredly reliable because it preserved "all of the other elements of the confrontation right": testimony under oath, the opportunity for "contemporaneous cross-examination," and the ability of the judge and jury to view the demeanor of the witness during testimony. ${ }^{65}$ Thus the "critical inquiry" in the case was whether the video testimony was "necessary to further an important state interest." "requisite finding of necessity ... be a case-specific one." The test established in Craig still governs video testimony in child molestation

60 See id at 840-43. See also Md Crim Proc Code Ann $\S 11-303$ (2002) (codifying Maryland's current child victim closed-circuit testimony procedure).

61 Id at 849-50 ("[T] witnesses appearing at trial, we cannot say that such confrontation is an indispensable element of the Sixth Amendment's guarantee of the right to confront one's accusers."). This general principle is consistent with previous Supreme Court cases, including, for example, Chambers v Mississippi, 410 US 284, 295 (1973) ("Of course, the right to confront [physically] is not absolute and may, in appropriate cases, bow to accommodate other legitimate interests in the criminal trial process").

62 See Craig, 497 US at 850 (listing cases and stating that "[w]e see no reason to treat the face-to-face component of the confrontation right any differently, and indeed we think it would be anomalous to do so").

63 See id at 849-50.

64 Id at 850 .

65 Id at 851 .

66 Id at 852 (noting that the Court has "of course" recognized in previous cases that a state's interest in protecting child sex-crime victims from further trauma and embarrassment is important).

67 Id at 855. 
cases, ${ }^{68}$ though its applicability to cases dealing with at-trial, two-way video testimony by unavailable witnesses is in dispute. ${ }^{69}$

\section{B. Physical Confrontation and Unavailable Witnesses}

The admissibility of prior testimony of unavailable witnesses in criminal cases is governed by Crawford. In this landmark case, the Supreme Court held that testimonial out-of-court statements (such as depositions, previous trial testimony, or statements to police officers) by absent witnesses were generally barred from criminal prosecutions by the Confrontation Clause. Crawford carved out a limited exception when the witness was unavailable to appear at trial and the defendant had a prior opportunity to cross-examine the witness.

Though foreign witnesses unwilling to travel are beyond the reach of subpoenas and are thus unavailable, ${ }^{7}$ their videoconference testimony is not given prior to trial. Crawford did not address testimony given during trial. Further, Crawford was based almost entirely on legal history and the state of the common law at the time of the Sixth Amendment's adoption, and the eighteenth-century common law obviously did not address the issue of testimony given at trial by an absent witness. ${ }^{72}$ Indeed, Crawford is silent on the issue of whether, at the time of the adoption of the Confrontation Clause, the physical presence of the defendant was required at cross-examination. Thus the applicability of Crawford to in-court video testimony is weak at best. ${ }^{73}$

While several circuits have held that physical confrontation is not required for prior deposition testimony to be constitutional, ${ }^{74}$ the Federal Rules of Criminal Procedure evince a preference for physical confrontation when prior deposition testimony is to be introduced

\footnotetext{
68 See, for example, United States v Bordeaux, 400 F3d 548, 552-55 (8th Cir 2005).

69 See Part III.

70 See 541 US at 54 ("[T]he common law in 1791 conditioned admissibility of an absent witness's examination on unavailability and a prior opportunity to cross-examine. The Sixth Amendment therefore incorporates those limitations."). See also the discussion of Crawford's historical analysis of the Confrontation Clause in Part I.A.

71 See FRE 804(a) for a widely accepted definition of unavailability. See also note 160.

72 See Crawford, 541 US at 54 ("[T]he 'right ... to be confronted with the witnesses against him,' is most naturally read as a reference to the right of confrontation at common law.") (ellipses in original). See also note 91 and accompanying text for a discussion of why Crawford does not resolve the circuit split over the constitutionality of videoconference testimony.

73 See note 12 for a discussion of whether video testimony may be considered "in court" testimony. See text accompanying notes 86-91 for a discussion of the majority's argument in United States v Yates, 448 F3d 1307, 1314 n 4 (11th Cir 2006), that Crawford does not apply to live video testimony.

74 See note 50 and accompanying text.
} 
against the defendant at trial. ${ }^{15}$ Rule 15 provides that depositions may be taken for use at trial in lieu of trial testimony, at the court's discretion, "because of exceptional circumstances and in the interest of justice." The Rule requires (with some exceptions) that the defendant be given the right to attend and that the Government must pay the defendant's expenses to facilitate attendance if the defendant chooses to exercise his right and cannot afford the travel on his own. ${ }^{n}$ Thus, Rule 15 depositions at least supply a potential alternative to video testimony at trial where witnesses are unavailable. ${ }^{78}$

\section{CIRCUIT SPLIT REGARDING THE CONSTITUTIONALITY OF TWO- WAY VIDEO TESTIMONY AT TRIAL BY AN UNAVAILABLE WITNESS}

Since Craig was decided, two circuit courts have been faced with Confrontation Clause challenges to two-way videoconference testimony by foreign or otherwise unavailable witnesses. The Second Circuit has held that such testimony is constitutional, while the Eleventh Circuit has recently found it unconstitutional, reversing a conviction that relied upon the video testimony of foreign witnesses. The circuits disagree on whether the Craig test applies to two-way video testimony, and also on the constitutional relevance of the availability of $\mathrm{FRCrP}$ 15 depositions as an alternative to in-court video testimony.

Part III.A presents the Second Circuit's view that the Craig test should not apply to video testimony and that such testimony is at least as constitutional as are Rule 15 depositions. Part III.B presents the Eleventh Circuit's view that the Craig test must apply to in-court video testimony and that such testimony is unconstitutional because it deprives defendants of the physical confrontation that Rule 15 depositions typically provide.

\section{A. The Second Circuit: Two-Way Video Testimony Is Constitutional}

The Second Circuit, in United States $v$ Gigante, ${ }^{79}$ held that videoconference testimony was not subject to the Craig test and did not

75 See Yates, 438 F3d at 1333-34 (Marcus dissenting) (stating that a defendant is entitled to be present at a Rule 15 deposition, but that the entitlement "simply comes from the terms of Rule 15 itself" and not from the Confrontation Clause).

76 FRCrP 15(a)(1). Exceptional circumstances generally entail situations where the witness is otherwise unavailable for trial and the absence of his testimony would result in an injustice. See United States v Drogoul, 1 F3d 1546, 1552 (11th Cir 1993).

77 FRCrP 15(c)-(d). Note that defendants who are in custody can lose their right to attend by acting disruptively and defendants who are not in custody must request to be present. FRCrP 15(c)(1)-(2).

78 See Yates, 438 F3d at 1316-17.

79166 F3d 75 (2d Cir 1999). 
violate the Confrontation Clause. ${ }^{\mathrm{s} 0}$ In Gigante, the trial court had permitted an ill witness in the Witness Protection Program to testify via videoconference. ${ }^{81}$ The Second Circuit affirmed, holding that the videoconference procedure preserved all the key constitutional elements of in-court testimony: the witness "was sworn; he was subject to full crossexamination; he testified in full view of the jury, court, and defense counsel; and [he] gave this testimony under the eye of Gigante himself." ${ }^{\text {,82 }}$

The court declined to apply the Craig test and distinguished the instant case from Craig, finding that while Craig involved a one-way video procedure that prevented the witness from viewing the defendant, the two-way video procedure at issue allowed for "face-to-face confrontation." ${ }^{83}$ The court then compared video testimony by an unavailable witness to (constitutionally acceptable) Rule 15 deposition testimony, arguing that the video testimony afforded greater Confrontation Clause protection and thus was constitutionally permissible so long as a Rule 15 deposition would be permissible. ${ }^{84}$ The court held that video testimony was constitutionally permissible wherever a trial court has made a finding of "exceptional circumstances" (like witness unavailability) per the analogous Rule 15 standards. ${ }^{85}$

\section{B. The Eleventh Circuit:Two-Way Video Testimony Is Unconstitutional}

The Eleventh Circuit, in United States $v$ Yates, ${ }^{86}$ held that the Craig test applied to videoconference testimony by an unavailable foreign witness - and found that such testimony did not pass the test. ${ }^{87}$ The trial court had allowed two witnesses in Australia to testify via videoconference about an Internet fraud conspiracy they were en-

80 See d at $80-82$ ("Because [the trial judge] employed a two-way system that preserved the face-to-face confrontation celebrated by $\mathrm{Coy}$, it is not necessary to enforce the Craig standard in this case.").

81 See id at 80 . Though Gigante does not deal with a foreign witness but rather an American citizen unavailable to testify, the constitutional analysis is essentially the same. The witness in Gigante was, however, uniquely unsuited to a Rule 15 deposition because of his membership in the Witness Protection Program (allowing the defendant to travel to his home would have blown the witness's cover). See id at $\mathbf{8 1}$. However, this fact did not materially impact the court's constitutional analysis, as the availability of a Rule 15 deposition as an alternative would only have been relevant if the court had found the Craig test applicable.

82 Id at 80 .

83 Id at 81 . See also note 23. A few district courts have implicitly endorsed this approach. See United States $v$ Beaman, 322 F Supp 2d 1033, 1035 (D ND 2004) (holding that videoconference testimony would not deprive the defendant of his confrontation right because the witness and the defense could see and speak to each other in real time).

84 See Gigante, 166 F3d at 81.

85 See id. See also FRCrP 15(a)(1). Unavailability is defined for the purposes of Rule 15 by reference to FRE 804(a). See Gigante, 166 F3d at 81 . See also notes $76,160$.

86438 F3d 1307 (11th Cir 2006) (en banc).

87 See id at $1312-18$. 
gaged in with the defendant. ${ }^{88}$ Sitting en banc, the Eleventh Circuit vacated the convictions of the defendants, holding that the video testimony violated their Confrontation Clause rights.

The court found that the standard for testimonial hearsay established in Crawford was not applicable to video testimony because Crawford addressed testimonial statements made prior to trial, whereas Yates concerned testimony "presented at trial." ${ }^{\prime 00}$ The majority essentially argued that Crawford should be interpreted narrowly and is only applicable to traditional means of testimony given prior to trial. This argument is supported by Crawford's focus on historical interpretations of the confrontation right."

The Yates court then rejected the Gigante approach to the Craig test, noting that the Second Circuit is alone among circuits in differentiating between one-way and two-way video testimony in its constitutional analysis." Thus, according to the court, "[b]ecause Defendants were denied a physical face-to-face confrontation with the witnesses against them at trial, we must ask whether the requirements of the Craig rule were satisfied." ${ }^{93}$ The court also cited its previous decision in Harrell v Butterworth, ${ }^{4}$ approving the Craig test as the proper test for in-court video testimony.

88 See id at 1309-10.

89 See d at 1317-18.

90 Id at $1314 \mathrm{n} 4$.

91 See 541 US at 54 (arguing that the language of the Sixth Amendment "is most naturally read as a reference to the right of confrontation at common law" and that the "Sixth Amendment therefore incorporates" the common law requirements of unavailability and a prior opportunity to cross-examine). The common law does not explicitly sanction (or even contemplate) testimony given at trial without the physical presence of both the defendant and the witness. Neither does Crawford, nor the common law it examines, insist upon physical presence at a cross-examination as a prerequisite to admitting deposition testimony at trial. See Parts II.B and IV.C. Finally, Crawford did not have occasion to compare the constitutionality of in-trial testimony without presence to that of physical presence at a pretrial deposition. Thus Crawford does not address whether cross-examination at trial and via videoconference is sufficient, without physical presence, to render such testimony constitutional. We must look to Craig and its related cases for the answer.

92 See Yates, 438 F3d at 1313-14 (comparing the Second Circuit's approach to that of the Sixth, Eighth, Ninth, and Tenth Circuits). See also note 23.

93 Id at 1314.

94251 F3d 926 (11th Cir 2001).

95 See id at 930-31. A few other courts ruling on the constitutionality of video testimony have also applied the Craig test in one manner or another. See, for example, United States $v$ Shabazz, 52 MJ 585, 594 (Navy-Marine Corps Ct Crim App 1999) (applying the Craig test and stating in dicta that a military judge could find that denial of face-to-face confrontation at trial is necessary to further an important public policy for adult witnesses in addition to child witnesses); State v Sewell, 595 NW2d 207, 212 (Minn Ct App 1999) (applying a lenient version of the Craig test and holding that the public policy prong of the Craig test was satisfied "[o]nce the unavailability of the witness and the necessity of the testimony have been demonstrated"). See also United States $v$ Navarro, 169 F3d 228, 237, 239 (5th Cir 1999) (finding that FRCrP 43(a)(3) re- 
In Harrell, the trial court had permitted the testimony of two robbery victims via satellite transmission. The Florida Supreme Court upheld the use of video testimony, applying the Craig test but finding that the video testimony served important public policies and was therefore constitutional. ${ }^{\text {\% }}$ The court identified three public policy reasons for allowing the testimony: the witnesses were beyond the subpoena power of the court, one of the witnesses was too ill to travel, and the witnesses were essential to the case. ${ }^{97}$ Further, it was in the state's interest to expeditiously and justly resolve criminal cases. ${ }^{98}$ Reviewing the defendant's subsequent federal habeas petition to a district court, the Eleventh Circuit held that the Florida Supreme Court's application of the Craig test was "neither contrary to, nor involved an unreasonable application of," clearly established federal law."

However, Yates repudiated the idea that judicial findings of witness unavailability, witness importance, and administrative ease were sufficient to pass the Craig test, at least in federal court. Though the district court in Yates made case-specific findings that video testimony was necessary to further two important public policies-providing the factfinder with crucial evidence when the witnesses were unavailable and expeditiously resolving the case - the Yates court held that these public policies were insufficient to justify the use of video testimony. ${ }^{100}$ The court stated that the trial court "made no case-specific findings of fact that would support a conclusion that this case is different from any other criminal prosecution in which the Government would find it convenient to present testimony by two-way video conference" and expressed concern that every prosecutor who wanted to use videoconference testimony could assert these grounds and thus bypass the Craig test. ${ }^{101}$ Indeed, the court indicated that there could be no valid case-specific finding that video testimony was "necessary" under the Craig test so long as a Rule 15 deposition was available."

\footnotetext{
quires physical presence at sentencing because "[i]n the most important affairs of life, people approach each other in person, and television is no substitute for direct personal contact" and suggesting that "[v]ideo conferencing would seemingly violate a defendant's Confrontation Clause rights at [ ] other stages of trial") (quotation marks omitted).

96 See Harrell v State, 709 S2d 1364, 1368-69 (Fla 1998).

97 See id at 1369-70 ("The three concerns, taken together, amount to the type of public policy considerations that justify an exception to the Confrontation Clause.").

98 See id at 1369.

99 See Harrell v Butterworth, 251 F3d at 931.

100 Yates, $438 \mathrm{~F} 3 \mathrm{~d}$ at 1316.

101 Id.

102 See id at 1316 \& n 8 (stating that where a Rule 15 deposition is available, the lack of necessity of video testimony is "strikingly apparent").
} 
Echoing Coy, ${ }^{103}$ the court stressed that confrontation through a video monitor is not the same for purposes of the Confrontation Clause as physical confrontation. ${ }^{104}$ It proposed that a Rule 15 deposition, which had been available, provides a constitutionally superior alternative to video testimony because it "guarantee[s] the defendant's right to physical face-to-face confrontation by specifically providing for his presence at the deposition." ${ }^{105}$ Thus, the court held that "under the circumstances of this case (which include the availability of a Rule 15 deposition)" the asserted public policies were "not the type of public policies that are important enough to outweigh the Defendants' rights to confront their accusers face-to-face." ${ }^{106}$ The court's approval of the Rule 15 deposition procedure as a rough constitutional equivalent to actual in-court confrontation was central to its rejection of the asserted public policies under the Craig test.

Why did the Eleventh Circuit in Yates engage in a much stricter Craig analysis than the one it approved in Harrell v Butterworth? Unlike Rule 15, Florida's Rule of Criminal Procedure 3.220 does not provide for government funding for defendants to attend depositions. It appears that the court was establishing in its two videoconferencing cases that the content of the relevant procedural rules may dictate whether video testimony violates the Confrontation Clause under Craig and that where state rules do not provide transportation for defendants to attend depositions, video testimony is permissible because no viable face-to-face alternative exists.

It is likely, however, that the court was also influenced by an intervening event that caused it to be more inclined towards a stricter application of Craig to video testimony: the Supreme Court's refusal to pass on to Congress a proposed amendment to FRCrP 26 that would have explicitly permitted video testimony upon a finding of "exceptional circumstances." Circuit decided Harrell $v$ Butterworth), Justice Scalia filed a brief

103487 US at 1020.

104 See Yates, 438 F3d at 1315.

105 Id at 1317. Recall that the standard applied by courts to Rule 15 depositions does not require that the defendant attend a deposition in order to render it constitutionally admissible. See notes 50,75 .

106 Id at 1316.

107 This is essentially the same standard applied to Rule 15 depositions. See note 76 and accompanying text. The Advisory Committee Note to the proposed amendment indicated that the rule was drafted in accordance with the Second Circuit's rationale in Gigante, 166 F3d at 81 ("[C]ontemporaneous testimony via closed circuit televising affords greater protections of [ ] confrontation rights than would a deposition.") (quoting the trial court with approval). The Note also argued, as did the court in Gigante, that the Craig test should not apply to two-way video testimony. Proposed Amendments to the Federal Rules of Criminal Procedure 74-76, online at http://www.uscourts.gov/rules/supct1101/CRRedline.pdf (visited Sept 12, 2007). 
statement explaining why the Court had refused to approve the amendment and reporting that the majority's view was that the proposed rule was "of dubious validity under the Confrontation Clause." ${ }^{108}$ Scalia argued that the Craig test should be applied, and that case-specific findings should be required for denying the right to a physical confrontation of the witness. ${ }^{109}$ He then emphasized that the Court applies different tests for in-court and out-of-court testimony, indicating that applying the standard for out-of-court depositions to in-court video testimony was inappropriate. ${ }^{110}$ Further, he mentioned that Rule 15 depositions generally afford defendants the right to physical confrontation during the deposition. ${ }^{11}$

Although Scalia's statement is short and the arguments about Rule 15 depositions were made in the context of refuting the Committee's argument that video testimony should be acceptable wherever "exceptional circumstances" are shown, they appear to form the basis for the Eleventh Circuit's holding in Yates. Indeed, the Yates court discussed the rejection of the amendment and cited Scalia's statement in its opinion. ${ }^{112}$ While Scalia's statement has no official legal weight and may not reflect the reasoning of the other judges in the majority who rejected the proposed amendment to Rule 26, it appears to have led the Eleventh Circuit to take a very strict approach to video testimony while favoring Rule 15 depositions.

\section{The Need for a Resolution}

Neither of the circuit courts addressing videoconference testimony has devised a satisfactory resolution of the issue. Under the analysis in Gigante, videoconference testimony received in a courtroom during a trial is treated doctrinally like a form of out-of-court testimony. ${ }^{113}$ In addition, the Gigante court's decision not to apply the test established in $\mathrm{Craig}^{114}$ was based on a distinction between one-way and two-way video

108 Statement from the Supreme Court of the United States to Congress on the Amendments to Rule 26(b) of the Federal Rules of Criminal Procedure 1 (Apr 29, 2002) ("Rule 26 Statement"), online at http://www.uscourts.gov/rules/CR-26b.pdf (visited Sept 12, 2007).

109 See id at 1-2. See also Antonin Scalia, A Matter of Interpretation 43-44 (Princeton 1997) (noting that the closed-circuit testimony in Craig was a "reasonable enough procedure," but defending his dissent on textual grounds).

110 See Rule 26 Statement at 1-2 (cited in note 108). See also note 39.

111 Id at 2-3.

112438 F3d at 1314-15 (stating that to accept the Government's arguments for admitting the video testimony would "require that we disregard the history of the proposed amendments to Rule 26").

113 See 166 F3d at $80-82$.

114497 US at 850 (requiring furtherance of an important public policy and an assurance of reliability to permit testimony without physical confrontation). 
testimony that numerous other circuit courts have rejected. ${ }^{115}$ Thus, the current doctrinal basis for allowing two-way video testimony is weak.

The holding in Yates, ${ }^{116}$ while more formally sound in the sense that it at least applies the Craig test, creates practical problems for federal courts with valid reasons for wanting to use video testimony rather than Rule 15 depositions. It sets a far higher constitutional standard for contemporaneous video testimony than for stale testimony taken by deposition. Neither does the rationale of Yates have the clarity of many other formalistic, text-based constitutional interpretations; instead, it seems to hold that the text of Federal Rule of Criminal Procedure 15 sets the constitutional standard of the Confrontation Clause, at least in federal cases. ${ }^{117}$ Instead of treating video testimony at trial like prior testimony (as did Gigante), it treats the uncertain possibility of confrontation at a Rule 15 deposition like the actual in-court confrontation of a witness. Neither the Second Circuit nor the Eleventh Circuit has provided a convincing answer to the question of whether and in what circumstances videoconference testimony is constitutional.

\section{RESOLUTION OF THE CIRCUIT SPLIT}

This Part attempts to resolve this difficult legal problem. Part IV.A analyzes the functional considerations that favor the use of video testimony at trial. Part IV.B discusses the doctrinal factors that favor the application of the Craig test to remote video testimony. Part IV.C proposes that courts should apply the Craig test to video testimony by unavailable witnesses, but that, contrary to Yates, the analysis under the test should be less strict than that applied in child molestation cases where the witness is actually available to appear in court. Part IV.D identifies the multitude of factual situations where the proposed standard would dictate that a court could permit video testimony under the Craig test because such testimony serves an "important public purpose." mony is necessary in these cases, courts can admit video testimony in numerous and varied situations without contradicting the Supreme Court's Confrontation Clause precedents.

115 See text accompanying note 92.

116438 F3d at 1312-18.

117 In state cases where the state's rules of procedure do not provide that the defendant must be able to attend a deposition, Harrell v Butterworth, $251 \mathrm{F3d}$ at 926, points towards an approach that lacks the flaws of Yates. In such state cases, courts should apply the Craig test as did the Florida Supreme Court in Harrell, finding that where a witness is unavailable and important to the case, an exception to the physical confrontation rule is justified under Craig. See Harrell $v$ State, 709 S2d at 1360-70. See also text accompanying notes 95-99.

118 Craig, 497 US at 850 . 


\section{A. Policy and Functional Considerations Favor Permitting Video Testimony}

Video testimony by unavailable witnesses is superior to Rule 15 deposition testimony in many ways relevant to the functional purposes of the Confrontation Clause. ${ }^{119}$ These functional advantages appear to have greatly influenced the court's opinion in Gigante, where the Second Circuit agreed with the district court that contemporaneous video testimony "afforded greater protection of Gigante's confrontation rights than would have been provided by a Rule 15 deposition." ${ }^{120}$ The central rationale for this conclusion arose from the court's comparison of video testimony to nonvideotaped Rule 15 depositions. Here, the functional advantage of video testimony is clear because it allows the factfinder to assess the witness's demeanor, an important element of Confrontation Clause protection. ${ }^{12}$

But there are reasons why contemporaneous, in-court video testimony is functionally superior even to videotaped deposition testimony. For example, live testimony gives the trial judge the ability to question the witness and to supervise the testimony. ${ }^{12}$ The Gigante court specifically argued that video testimony "allowed Gigante's attorney to weigh the impact of [the prosecution witness's] direct testimony on the jury as he crafted a cross-examination," a functional advantage over Rule 15 deposition testimony whether it is videotaped or not. ${ }^{123}$ Indeed, in a case directly comparing the benefits of videocon-

119 See Part I.B for a discussion of these purposes.

120 Gigante, $166 \mathrm{~F} 3 \mathrm{~d}$ at 81.

121 See id; Mattox v United States, 156 US 237, 242-43 (1895) (stressing the constitutional importance not only of cross-examination but of compelling the witness "to stand face to face with the jury in order that they may look at him, and judge by his demeanor upon the stand and the manner in which he gives his testimony whether he is worthy of belief"). Many courts have expressed a general preference for contemporaneous live testimony instead of depositions (particularly in criminal cases) - a preference largely based on the inability of jurors to assess witness demeanor. See, for example, United States v Drogoul, 1 F3d 1546, 1551-52 (11th Cir 1993) (citing also "the absence of procedural protections afforded" by foreign depositions); United States $v$ Bortnick, 2004 US Dist LEXIS 23086 *1-2, (ED Pa) (same).

122 See Kolb v County of Suffolk, 109 FRD 125, 127 (EDNY 1985) ("[W]hen depositions are submitted in place of live testimony, the trial judge is denied the opportunity to question the witness"). See also Yates, 438 F3d at 1334 (Marcus dissenting) ("[W]hen a witness testifies in a live videoconference, the judge can rule on objections immediately and otherwise manage the course of questioning and the conduct of counsel."). This may enhance the reliability and the clarity of the witness's testimony, both of which are important functional goals of the Confrontation Clause.

123 See 166 F $3 d$ at 81 . Note that the court cites an advantage to the defendant, who is the party challenging the use of video testimony. This is not as contradictory as it seems. Neither Gigante nor Yates actually requested that a Rule 15 deposition be taken. Instead, they objected to the introduction of video testimony in situations where a Rule 15 deposition was already infeasible due to the circumstances of the case. In Gigante, the court prevented the defendant from traveling to the witness's location for a deposition due to concerns about exposing the witness's location to his 
ferencing testimony to those of videotaped depositions, a judge found that videoconferencing testimony was superior because it would allow him to preside over the testimony as it was elicited, obviating reliability concerns raised by foreign methods of deposition. ${ }^{124}$ Additionally, "[t]he problem of unfairly shaping trial testimony in advance would be minimized since the testimony would be taken mid-trial, after the Government had already committed to a theory of the case.," ${ }^{125}$ Finally, video testimony is superior because it provides the court and the jury with "the simultaneity of a live witness" and up-to-date testimony."

Nor would the use of video testimony by foreign witnesses significantly deter the use of live testimony where such testimony is available. Overseas witnesses reluctant to travel to the United States generally undergo Rule 15 depositions in their own countries, and an increased use of video testimony would likely mean fewer Rule 15 depositions rather than fewer trips by overseas witnesses to the United States. Of course, the liberal use of video testimony for available witnesses would likely reduce the frequency of in-person testimony. This might raise serious concerns about the preservation of those functional elements of the Confrontation Clause right that are best served by actual physical confrontation. But video testimony is not currently an option for domestic witnesses who are anything less than seriously incapacitated and thus unavailable, so this objection lacks force. ${ }^{127}$

former colleagues in organized crime. See id at 81 . In Yates, the government's motion to admit video testimony was filed in the pretrial motion stage, likely too late for a Rule 15 deposition to be scheduled without causing significant delay. See 438 F3d at 1310,1318. Strategically, the defendants in these cases had an incentive to argue for the superiority of Rule 15 depositions over video testimony even if they would have preferred video testimony if faced with the choice before trial. See id at 1335 (Marcus dissenting) (noting that defendants "only mentioned Rule 15 by way of opposing the government's motion to permit video testimony").

Of course, a defendant might strategically prefer a Rule 15 deposition over video testimony because it may provide advantages in cross-examination or weaken the jury's bond with an adverse witness. But the defendant's strategic preference for a particular form of testimony is irrelevant to the Confrontation Clause analysis. See id. While defendants are likely to continue challenging video testimony when doing so would help their individual case, the practical and constitutional benefits to defendants in general should still weigh in the analysis of video testimony. Also note that many of the potential constitutional benefits of video testimony that are geared towards defendants also further the important public policy interest of providing reliable testimony in criminal cases.

124 See United States v Nippon Paper Industries Co, 17 F Supp 2d 38, 42 (D Mass 1998) (concluding generally that there are "advantages of video teleconferencing, especially as compared with videotaped depositions").

125 Id at 42 \& $\mathrm{n} 7$.

126 Id at $42-43$. This is in contrast to depositions, which may be taken months or years in advance of trial. See Helland, 35 Mich J L Reform at 721-22 (cited in note 6) ("Often ... the circumstances that make the witness unavailable at trial also dictate that the testimony be obtained well in advance of the trial.").

127 See text accompanying note 160 . 
At the margins, the availability of video testimony might make prosecutors less zealous when they ask foreign witnesses to attend trials in the United States, but the effect is likely to be minimal. If a prosecutor feels that the witness's physical presence will make his case more effective, he is likely to pursue that presence vigorously whether or not the alternative is a videotaped deposition or videoconference transmission.

Weighed against all of the functional benefits of video testimony is the intangible functional benefit of putting the witness in the same room as the defendant. The idea is that the physical presence of the defendant will make it more difficult for the witness to falsely accuse him or her. ${ }^{128}$ However, while Rule 15 depositions may generally have the advantage of providing physical confrontation between the witness and the defendant, they lack a benefit of video testimony that likely also discourages the witness from falsely accusing the defendant. Two-way videoconference testimony allows the witness to see (albeit via video) not only the defendant, but also the judge and jury, and thus demonstrates the seriousness of the proceeding and the effect of the accusations the witness is making. The truth-inducing effect of being able to see the judge and jury may or may not exceed the effect of being physically near the defendant in a deposition. But it further weakens the claim that Rule 15 depositions are functionally superior to video testimony in protecting a defendant's confrontation rights and promoting the efficient production of reliable testimony.

\section{B. Doctrinal and Practical Considerations Favor Applying the Craig Test to Video Testimony}

The approach advocated in Gigante, eschewing the Craig test and simply equating videoconference testimony with pretrial depositions, is doctrinally weak. One of the advantages of video testimony is that it is received in court during the trial. As such it should be treated as trial testimony and not out-of-court testimony for Confrontation Clause purposes. ${ }^{129}$ As the Gigante court pointed out, Rule 15 depositions are considered constitutional, and they can be used whenever the witness is unavailable and the witness's testimony is material to

128 See Coy, 487 US at 1019; United States v Bordeaux, 400 F3d 548, 554 (8th Cir 2005) (stating, in a child molestation case, that the virtual confrontation provided by video testimony does not provide the same "truth-inducing effect" as in-court, physical confrontation). This truth-inducing effect is certainly a benefit, though not a necessary one, as it is not available for hearsay testimony that courts have nonetheless found constitutional. See, for example, United States $v$ Mueller, 74 F3d 1152, 1156-57 (11th Cir 1996) (finding deposition testimony from a foreign witness constitutional even though the defendant did not attend the deposition). See also note 50.

129 In addition, in the absence of specific authority for video testimony in the Federal Rules of Criminal Procedure, it may be necessary for judges to treat video testimony as in-court testimony to provide a doctrinal basis for admitting it. See note 12 . 
the case. ${ }^{130}$ The court argued that there was no basis for holding video testimony to a higher standard. ${ }^{131}$ But whether or not it is ultimately the soundest approach, courts have consistently applied different constitutional standards for in-court and out-of-court testimony. ${ }^{132}$ For testimony given at trial, including video testimony, physical presence is generally required, and the only exception to the requirement thus far elaborated is that set forth in Craig.

Gigante attempted to get around this difficulty by refusing to apply the Craig test and holding that a two-way video system provided face-to-face confrontation as that term is used in Supreme Court decisions. ${ }^{1.33}$ But there is no support in the relevant cases or the history of the confrontation right for the proposition that confrontation by artificial means "preserves face-to-face confrontation" in the same manner as actual physical confrontation. ${ }^{134}$ Aside from the fact that most circuit courts have rejected it, this approach fails to reflect the strong preference in the Supreme Court's Confrontation Clause jurisprudence for in-person confrontation of witnesses testifying at trial. ${ }^{135}$ Further, by holding that video testimony is constitutionally analogous to face-toface confrontation under Coy, Gigante deviates from any plausible historical understanding of the Confrontation Clause. The only firm doctrinal basis for allowing trial testimony without physical confrontation of a witness by the defendant is under the Craig exception.

Additionally, it would be difficult for prosecutors to persuade circuit courts to avoid the Craig test and to admit video testimony on a showing of witness unavailability and material testimony (similar to the Gigante approach of applying the Rule 15 standard to video testimony ${ }^{136}$ ) in light of the Supreme Court's refusal to approve the proposed amendment to FRCrP 26 permitting video testimony wherever there are "exceptional circumstances." companying that refusal at least suggests that any ruling that the Craig test does not apply to video testimony is likely to be disapproved by the Supreme Court (despite the denial of certiorari in Gigante $^{138}$ ). While

130 See 166 F3d at 81.

131 See id.

132 See White $v$ Illinois, 502 US 346, 358 (1992) (holding that "the question of what in-court procedures are constitutionally required to guarantee a defendant's confrontation right once a witness is testifying ... is quite separate from that of what requirements the Confrontation Clause imposes as a predicate for the introduction of out-of-court declarations"). See also notes 12 and 91.

133 See $166 \mathrm{~F} 3 \mathrm{~d}$ at 81.

134 Id. See Rule 26 Statement at 2 (cited in note 108) for a critique of the Gigante court's conclusion. See also discussion in note 23.

135 See, for example, Coy, 487 US at 1019. See also note 128 and accompanying text.

136 See note 76 and accompanying text. See also Gigante, 166 F3d at 81.

137 See Part III.B.

138528 US 1114 (2000). 
Scalia's statement has no controlling authority, it will likely deter circuit courts from holding that the Craig test does not apply to two-way videoconference testimony at trial. It also suggests that the Supreme Court would favor evaluating video testimony under the Craig test against the available alternative of Rule 15 depositions in federal cases.

However, Scalia's reasoning and the Eleventh Circuit's adoption and expansion of that reasoning in Yates threaten to overemphasize the importance of physical confrontation at a Rule 15 deposition to the detriment of all of the other values that the Confrontation Clause embodies, including, most crucially, the right to a thorough crossexamination of the witness. ${ }^{139}$ Under the Yates court's application of the Craig test, there can be no valid case-specific finding that video testimony is necessary whenever a defendant can possibly be "placed in the same room" as the witness via a Rule 15 deposition. Indeed, while the trial court in Yates made case-specific findings of necessity pursuant to Craig, the Eleventh Circuit found them invalid, reasoning that they were insufficient due to the availability of a Rule 15 deposition. ${ }^{141}$ Though Scalia does suggest applying the Craig test to video testimony and briefly mentions that Rule 15 depositions provide faceto-face confrontation during a deposition, ${ }^{142}$ the Yates court takes Scalia's suggestion to its extreme.

This Comment seeks to avoid the use of Rule 15 depositions as a quasi-constitutional standard against which video testimony can never be found constitutionally permissible under Craig. ${ }^{143}$ As discussed in Part IV.D below, the overemphasis on physical confrontation and the use of Rule 15 depositions can lead in many cases to the denial of even more important rights embodied in the Confrontation Clause.

\section{The Proper Application of the Craig Test to Video Testimony of a Foreign or Otherwise Unavailable Witness}

Given the doctrinal considerations discussed in Part IV.B and Justice Scalia's disapproval of the Gigante court's rationale, the most fruitful approach for courts seeking to allow video testimony is to make case-specific findings that such testimony is "necessary to further an important public policy." 144 Recall also that, as discussed in Part IV.A, Rule 15 depositions do not provide all of the functional

139 See Part I.B.

140 See Yates, 438 F3d at $1317-18$ \& n 10 . See also text accompanying notes $100-06$.

141 Id at 1316.

142 See Rule 26 Statement at 2 (cited in note 108).

143 See Yates, 438 F3d at 1327 (Marcus dissenting) ("[The majority] has inexplicably accorded Rule 15 quasi-constitutional status as the exclusive means of obtaining overseas testimony.").

144 Craig, 497 US at 850. 
constitutional protections that actual physical, in-court confrontation provides. This Comment therefore proposes that the Craig test be applied to video testimony by foreign or otherwise unavailable witnesses (where the alternative is a Rule 15 deposition) in a less strict fashion than it was applied in Craig (where the alternative was traditional physical confrontation at trial).

As discussed in Parts I and II, the functional rather than formal purposes of the Confrontation Clause and the centrality of the right of cross-examination suggest that courts should not emphasize physical confrontation to the detriment of the other elements of the confrontation right. ${ }^{1.5}$ Courts should evaluate video testimony by reference to the alternative of Rule 15 depositions, but the potential confrontation available at these depositions should not be treated as a perfect alternative. As the Supreme Court has acknowledged, the Sixth Amendment's right to confrontation is "a trial right" that "includes both the opportunity to cross-examine and the occasion for the jury to weigh the demeanor of a witness." ${ }^{146}$ Thus, the fact that Rule 15 depositions provide physical confrontation only before trial rather than at the actual trial suggests that courts should often find that video testimony from unavailable foreign witnesses passes the Craig test-even where it serves public policies less important than protecting child witnesses from trauma. Further, courts should find that video testimony serves an important public policy where it protects the fundamental elements of the confrontation right better than a Rule 15 deposition would. This Part lays out these arguments in detail.

From an historical standpoint, the Confrontation Clause contemplates actual confrontation at trial before the trier of fact, and "[a] Rule 15 deposition falls far short of that ideal." 147 The common law recognized an exception to the general rule of confrontation at trial where a witness was unavailable and where there was prior crossexamination. ${ }^{148}$ There appear to be no cases in the English common law prior to the Constitution nor in American courts soon after it that face the issue of whether cross-examination by a defendant's lawyer or representative without the defendant's presence satisfied the common law requirement. Instead, though they generally assume that the

145 These elements include testimony under oath, the opportunity for the factfinder to assess the demeanor of the witness, and, most crucially, thorough cross-examination of the witness. See United States v Owens, 484 US 554, 560 (1988); Green, 399 US at 158. See also Delaware v Fensterer, 474 US 15, 22 (1985) (emphasizing the importance of "full and fair" cross-examination).

146 Barber $v$ Page, 390 US 719, 725 (1968). See also, for example, Pennsylvania $v$ Ritchie, 480 US 39,52-53 (1987) ("The opinions of this court show that the right to confrontation is a trial right.").

147 Yates, 438 F3d at 1333 (Marcus dissenting) (describing the Rule 15 deposition as a fallback procedure used only when the witness is unavailable).

148 See Crawford, 541 US at 54-55. 
defendant will take part in cross-examination, the cases and authorities from pre-Constitution English common law up to the present day that mention the possibility suggest that cross-examination without presence will satisfy the confrontation requirement. ${ }^{149}$ Further, the historical cases are clear in their preference for contemporaneous testimony given at trial rather than the use of depositions. ${ }^{150}$

Additionally, a textual interpretation of the clause indicates that physical presence at a deposition was not within the plain meaning of the text or central to the confrontation right. As the Supreme Court has repeatedly held, the text of the clause indicates that the confrontation right is a trial right, and thus "a literal interpretation of the Confrontation Clause could bar the use of any out-of-court statements when the declarant is unavailable [at trial]." ${ }^{\text {ist }}$ Even in a case like Coy, where the Court affirmed the strict "face-to-face" requirement (from which it later backed away in Craig), it acknowledged that the "asserted right to face-to-face confrontation at some point in the proceedings other than the trial itself" is not set forth in the text of the Confrontation Clause and is thus "not absolute, and may give way to other important interests." ${ }^{\text {, } 22}$ To be sure, physical presence at a Rule 15 deposition preserves a Confrontation Clause value identified in cases like Coy. But because it is not within the express historical or textual meaning of the clause, it is not worthy of the same doctrinal weight that is afforded to physical presence occurring at trial. And even the trial right has been qualified significantly by Craig.

When a foreign witness is unwilling to travel to the United States, the alternative to video testimony is not-as it was in Craig, and as is contemplated by the text and purpose of the Confrontation Clausein-person testimony at trial. Rather, the alternative is the use of outof-court testimony taken in the absence of the trier of fact. Therefore, the standard for finding that video testimony by an unavailable for-

149 See, for example, Fenwick's Case, 13 How St Tr 538, 591-92 (1696) (statement of Sir Shower) (stating the common law rule that a deposition could not be admitted where the defendant was "not present, nor privy, nor could have cross-examined [the witness]"); State v Campbell, 30 SCL (1 Rich) 124, 124-25, 132 (1844) (holding that for a deposition to be admissible at trial the defendant "must have been present; or, at least, had an opportunity of ... examining [the defendant]"); Douglas, 380 US at 418 ("[A]n adequate opportunity for cross-examination may satisfy the clause even in the absence of physical confrontation."). See also John Henry Wigmore, 2 Evidence in Trials at Common Law $\$ 1397$ at 1754 (Little, Brown 1904) ("There never was at common law any recognized right to an indispensable thing called confrontation as distinguished from cross-examination."). See note $\mathbf{1 7 6}$ for a list of numerous modern cases holding that physical presence is not required at Rule 15 depositions under the Confrontation Clause.

150 See Crawford, 541 US at 45 (describing the strict common law rules of unavailability), citing Lord Morley's Case, 6 How St Tr 770, 770-71 (1666).

151 Bourjaily v United States, 483 US 171, 182 (1987).

152 Coy, 487 US at 1020. 
eign witness furthers an important public policy should not be unduly rigorous, as it was in Yates. Instead, courts should find that video testimony serves an important public policy under the Craig test where the functional constitutional benefits of in-court video testimony outweigh the benefits of (potential) physical confrontation at a deposition taken prior to the trial itself.

In factual situations where the use of Rule 15 depositions would lead to the lack of a valid oath to ensure the reliability of the testimony, where the factfinder's ability to assess the witness's demeanor is compromised, or especially where adversarial cross-examination is unavailable or where the cross-examination available in a Rule 15 deposition will be significantly less effective than that available with video testimony, ${ }^{153}$ the Confrontation Clause values served by video testimony will outweigh those served by the mere physical presence of the defendant at a pretrial proceeding. ${ }^{154}$ In these situations, the functional loss of oath, visual demeanor assessment, or effective crossexamination will outweigh whatever practical benefit physical confrontation at a deposition may confer. ${ }^{155}$ There is no doctrinal reason to insist upon physical presence at a pretrial deposition where crossexamination is otherwise preserved. Indeed, by now, the doctrinal importance of oath, demeanor assessment, and especially crossexamination have been established as roughly equivalent to that of physical presence even at trial. ${ }^{156}$ When providing physical presence outside of trial would make oath, demeanor assessment, or effective cross-examination unavailable, the formal considerations are essentially a wash, and the functional considerations tilt towards not requiring physical presence when video testimony better preserves the other three values. Allowing video testimony in these situations is wholly consistent with the framework of Craig, and with that case's wellsupported finding that physical presence "is not the sine qua non of the confrontation right" or an "indispensable element" of the right."

153 Cross-examination might be significantly less effective due to procedural defects, reliability concerns, or the necessity for updated or contemporaneous testimony. See text accompanying notes $178-82$.

154 See Part IV.D for a further discussion of these factual situations.

155 See Part IV.A.

156 See Craig, 497 US at 847-50. See also Green, 399 US at 158-59 (discussing the importance and function of oath, cross-examination, and demeanor assessment); text accompanying notes 41-43 (describing the elements of the confrontation right); note 121 (discussing demeanor assessment).

157 Craig, 497 US at 847, 849-50. See also text accompanying notes $42-43$. 
Of course, Craig also found that physical presence (albeit at trial) was important, though not crucial. ${ }^{158}$ Thus, in accordance with Craig and other Supreme Court cases asserting the importance of physical presence, video testimony should not be permitted where a Rule 15 deposition will provide a valid oath; thorough, reliable, and effective cross-examination; and the opportunity (likely supplied by videotaping) for the factfinder to assess the demeanor of the witness as he or she testifies. In these cases, the importance of physical presence will likely outweigh the interests that would be served by video testimony. ${ }^{159}$

Similarly, video testimony will not pass constitutional muster when the witness in question is available to testify at trial. ${ }^{160}$ This situation might arise with regard to United States citizens who are currently overseas, but nonetheless subject to a Unites States court's subpoena power under 28 USC $\$ 1783 .{ }^{161}$ While the Craig test would still apply, there would be absolutely no important functional confrontation purpose served by the use of video testimony rather than actual at-trial physical testimony, and mere convenience for the prosecution would not qualify as an "important public policy" under Craig. In these situations, and where unavailable witnesses can receive Rule 15 depositions that wholly preserve the values of oath, thorough crossexamination, and demeanor assessment, courts should find that video testimony does not pass the Craig test. In all other situations, permitting video testimony despite the absence of direct physical confrontation is consistent with the central purposes of the Confrontation Clause and the Supreme Court's Confrontation Clause cases.

158 See id at 849-50 ("[T]hough we reaffirm the importance of face-to-face confrontation with witnesses appearing at trial, we cannot say that such confrontation is an indispensable element of the Sixth Amendment's guarantee of the right to confront one's accusers.").

159 Whether or not depositions taken in Australia, at issue in Yates, would meet this standard is unclear. It appears possible, though it largely depends on local immunity and privilege law and the willingness of Australian officials to accommodate requests for full crossexamination and videotaping. Yates ignores the issue. Instead, its requirement of a "case-specific finding that the witnesses and defendants could not be placed in the same room" overvalues physical presence at deposition and threatens to prohibit video testimony in many situations where it would be necessary to preserve important elements of the confrontation right. See Yates, $438 \mathrm{~F} 3 \mathrm{~d}$ at 1317. See also Treaty between the Government of the United States of America and the Government of Australia on Mutual Assistance in Criminal Matters, Art VIII, Treaty Doc 105-27 (1997), reprinted in 2117 UNTS 157.

160 Unavailability as a constitutional matter appears to track the plain meaning of the term - the prosecution must at least demonstrate that the witness cannot be produced at trial for some valid reason. See Roberts, 448 US at $65-66$, overruled in part on other grounds by Crawford, 541 US at $67-68$. If the witness is within the subpoena power of the court, he will generally be held to be available; the prosecution must make an effort to procure him. See Barber, 390 US at 723. FRE 804(a) lists situations where witnesses are considered unavailable for the purposes of hearsay analysis. See also notes 71,85 .

161 See note 8. 


\section{Valid Case-Specific Findings under Craig That Video Testimony Is Necessary}

This Comment demonstrates that courts can make case-specific findings that video testimony is required to further important public policies even where Rule 15 depositions are legally available. It proposes that the circuit split can essentially be resolved under the nonstrict Craig analysis proposed in Part IV.C because courts can make valid case-specific findings that video testimony is necessary to further an important public policy in a very wide variety of situations. Most clearly, judges should make sound case-specific findings that video testimony is necessary in the many cases where Rule 15 depositions to be taken in foreign countries according to foreign procedures are deficient for some reason. ${ }^{162}$ Reviewing the relevant case law reveals

162 Video testimony voluntarily given by foreign nationals is not likely to implicate the laws and procedures of the foreign nation. An analogy can be drawn to depositions by stipulation pursuant to FRCP 29 and FRCrP 15(h), which do not require the participation of foreign officials or courts. See Bruno A. Ristau, 1 International Judicial Assistance: Civil and Commercial § 3-2-3 at 115 (International Law Institute 2000). Such depositions are available if agreed to by the parties and approved by the court, unless prohibited by national law. Id. See also Popular Imports, Inc $v$ Wong's International, Inc, 166 FRD 276, 280 (EDNY 1995) (refusing to suppress evidence, even though the plaintiff argued that Chinese law prohibits depositions except by a request through diplomatic channels, because a deposition had already been taken without incident).

Even where such laws exist, it is unlikely that video testimony is mentioned in the laws or runs afoul of them in the explicit way that a deposition occurring on foreign soil does. For example, China's rejection of voluntary depositions is based on a concern about violations of its territorial sovereignty and the potential inability of American officials to give valid oaths "in China." See U.S. Department of State, Obtaining Evidence in China, online at http://travel.state.gov/ law/info/judicial/judicial_694.html (visited Sept 12,2007). Video testimony is taken under oath given by an officer located in a United States court, and no judicial officers or attorneys need enter the foreign country. Though the exact legal status of an oath given via videoconference in foreign nations with laws prohibiting United States officers from physically entering the nation's territory to give oaths is a complex question, it is unlikely that video testimony transmitted by private parties in a foreign nation will violate laws that were written with territorial encroachment by United States officials in mind. Nor are the laws likely to change even if videoconference testimony becomes more widely used, as foreign countries are unlikely to notice private citizens giving video testimony in the first place, and thus there may be little incentive to pass laws explicitly prohibiting such activities.

In countries where foreign depositions by stipulation are available for willing witnesses, do such depositions provide a viable alternative to the flawed depositions discussed below? No, for two reasons. First, as mentioned above, depositions occurring on foreign soil are more intrusive than mere videoconferencing, and the intrusiveness of the procedures may dictate the use of international agreements rather than informal deposition procedures conducted under the Federal Rules. See Société Nationale Industrielle Aérospatiale v United States District Court, 482 US $522,544-46$ (1987) (holding that in a particularized analysis of whether the principles of international comity require the use of an international agreement, the intrusiveness of the discovery procedure should be considered). Government prosecutors (and judges) will likely prefer to use a letter of request under a bilateral criminal assistance treaty or a letter rogatory directed to the foreign authority when seeking to actually travel to a foreign country to conduct a deposition. See Restatement (Third) of the Foreign Relations Law of the United States $\S 473$, comment $i$ (1987) (stating that, at least in the civil context, discovery, such as a physical inspection of a fac- 
numerous situations where Rule 15 depositions can clearly be found constitutionally inferior to in-trial video testimony on a valid, casespecific basis. ${ }^{16}$

In many foreign countries (especially civil law countries), oral questioning by counsel is generally not permitted, and depositions are conducted by magistrates. ${ }^{164}$ When unavailable foreign witnesses are located in such countries, the court should make a case-specific finding that the witness should testify via videoconference in order to allow counsel to examine and cross-examine the witnesses. ${ }^{165}$ Allowing the defense to conduct cross-examination during videoconference testimony is more consistent with the principles of the Confrontation Clause than is allowing a third party to do so before trial while the defendant is present, especially given the central importance of cross-

tory, that can only be carried out by traveling to a foreign state should be taken pursuant to international agreements). See generally Michael Abbell and Bruno A. Ristau, 3 International Judicial Assistance: Criminal $\$ \S 12-3-3,12-4-1$ (International Law Institute 2000) (describing letters rogatory and the types of assistance foreign nations provide). Depositions taken pursuant to these requests will almost certainly be taken pursuant to the host country's procedures and laws. See id $\S \S 12-3-3(2), 12-4-6(1)$. See also, for example, Treaty between the Government of the United States of America and the Government of Canada on Mutual Legal Assistance in Criminal Matters, Art VII, I 2, Treaty Doc 100-14 (1985), reprinted in 24 ILM 1092 ("A request shall be executed in accordance with the law of the Requested State."). By contrast, the less intrusive use of videoconferencing does not implicate international comity principles nearly as much, and its use is not explicitly covered by existing bilateral criminal assistance treaties. See id at Appendix D (collecting mutual assistance treaties between the United States and other nations in criminal matters).

Second, even if a court were to approve a deposition proceeding on foreign soil without the use of procedures set forth in a bilateral treaty (or otherwise pursuant to a letter of request), the avoidance of the use of the bilateral treaty would also entail the loss of the ability under the treaty to transfer a defendant in custody to the foreign country to attend the deposition. See, for example, Treaty on Mutual Legal Assistance in Criminal Matters between the United States of America and the Kingdom of Spain, Art 11, Il 2 (1990), reprinted in 1730 UNTS 113 (providing for the transfer of persons in custody in a requesting state to the receiving state). In other words, by avoiding the host country's legal system, the court would also lose the necessary benefit of having the host country take custody of the criminal defendant while he is in their territory. As discussed in the text accompanying notes 176-79, Rule 15 depositions where a defendant is not physically present are constitutionally inferior to video testimony.

163 Note that these examples, largely taken from circuit court cases, represent only a fraction of the countries whose deposition procedures differ from United States procedure in ways that impact the confrontation rights of defendants. These cases represent clear examples of courts upholding Rule 15 depositions despite potential constitutional deficiencies.

164 See, for example, Drogoul, 1 F3d at 1555 (Italy); United States v Sturman, 951 F2d 1466, 1480-81 (6th Cir 1991) (Switzerland; also, though Swiss law forbids verbatim transcription of depositions, the court found the use of summaries of depositions permissible); United States $v$ Salim, 855 F2d 944, 951 (2d Cir 1988) (France).

165 Videoconference testimony would be carried out according to United States procedure, as the witness is appearing entirely in a United States judicial forum. Though the witness is still physically present in the foreign country, he would be treated by the United States court as though he had traveled to the United States. See note 162. 
examination to the confrontation right. ${ }^{166}$ Case-specific findings might also be appropriate in cases where it is unclear what kind of deposition procedures a foreign country will allow ${ }^{167}$ or where the foreign judge imposes time limits on cross-examination of a witness. ${ }^{168}$

In some countries, the law does not allow magistrates to administer an oath to witnesses who themselves are facing criminal charges. ${ }^{169}$ Though the Yates court declined to rule on the issue of whether court clerks in the United States can administer oaths to foreign witnesses testifying via video, 28 USC $\$ 953$ may permit the administration of such oaths. ${ }^{170}$ Indeed, such oaths were administered by the trial courts in Yates and Harrell. ${ }^{171}$ An oath administered to a witness testifying via videoconference, if valid, subjects the witness to prosecution for perjury in the United States. Nor is the threat of such prosecution an empty one; perjury may be covered by extradition treaties between the United States and foreign countries. ${ }^{12}$ Thus, video testimony may be necessary to administer a valid oath to unavailable overseas witnesses. Because testimony under oath is an important element of the Confrontation Clause right and a crucial guarantor of the reliability of testimony, ${ }^{173}$ courts should make a case-specific finding that video testimony is permissible when an oath cannot be administered during a Rule 15 deposition occurring in a foreign country.

Some countries prohibit the videotaping of depositions. ${ }^{174}$ In such cases, a court should make a case-specific finding that video testimony

166 See discussion in Part I.B. See also note 123 for a discussion of why benefits to defendants should weigh in the Confrontation Clause analysis. Of course, the government's ability to conduct direct examination of a witness might also constitute an important public policy served by video testimony.

167 See, for example, Salim, 855 F2d at 952 ("As was demonstrated in this case, the parties and the court may not always know beforehand just what type of examination a foreign nation may permit the attorneys to conduct.").

168 See, for example, United States $v$ Casamento, 887 F2d 1141, 1173 (2d Cir 1989) (describing how, despite the defense attorney's complaints, a Swiss judge limited the time of crossexamination to the period used by the prosecution for direct examination).

169 Id at 1174-75 (finding that the use at trial of depositions of witnesses taken in Switzerland was constitutional despite the lack of an oath).

170 Though the issue has gone unaddressed by the courts, see Prosecutor's Yates Brief at 43-46 (cited in note 12) for the argument that 28 USC $\$ 953(2000)$ should be held to authorize oaths given via videoconference. Certainly, there is nothing in the text of the statute that affirmatively requires physical presence for giving oaths.

171 See Yates, 438 F3d at 1310; Harrell v Butterworth, 251 F3d at 929. See also Prosecutor's Yates Brief at 47 for a detailed description of the oaths in Yates.

172 See, for example, Extradition Treaty, May 8,1976, US-Australia, TIAS No. 8234, 27 UST 957.

173 See Owens, 484 US at 560 (holding that a court need not search for other indicia of reliability of hearsay testimony where oath, cross-examination, and demeanor assessment are present); Green, 399 US at 158-59 (discussing the truth-inducing effect of the penalty of perjury).

174 See, for example, United States v McKeeve, 131 F3d 1, 10 (1st Cir 1997) (noting that England prohibits videotaping of depositions); Salim, 855 F2d at 947 (noting that France prohib- 
is necessary to allow the jury to assess the witness's demeanor, another crucially important element of the Confrontation Clause right. ${ }^{17}$

Additionally, many cases have approved the use of depositions of foreign witnesses where the defendant was denied (often explicitly by the host country) the opportunity to physically confront the witness. ${ }^{1.0}$ Alternatively, defendants may not be able to travel to a foreign country to attend Rule 15 depositions because they may reasonably fear incarceration by the foreign country for crimes committed there. ${ }^{177}$ In cases where the defendant will not be able to physically confront the witness in a Rule 15 deposition procedure, the constitutional comparison is between depositions before trial without physical confrontation or testimony at trial in front of the jury without physical confrontation. In these situations, courts can clearly make case-specific findings that in-court video testimony will better protect the defendant's Confrontation Clause rights and provide better and more reliable testimony for trial than will a Rule 15 deposition.

Judges may also be able to make valid case-specific findings under Craig even in situations where Rule 15 depositions are not clearly deficient. For instance, judges might make case-specific findings of necessity in cases where they feel that they should personally supervise the witness's testimony in order to ensure its reliability for use at trial. ${ }^{178}$ Such situations may be especially likely to arise where the deposition would not occur before a judicial officer in the foreign

its both video and audio taping of depositions). Note that foreign courts that do not allow videotaped depositions on their soil would not be at all involved with video testimony to the United States, unless the foreign country's law explicitly so directed.

175 See note 121 and accompanying text.

176 See, for example, United States v Medjuck, 156 F3d 916, 920 (9th Cir 1998) ("The Government was unable to secure Medjuck's presence at the Canadian depositions because there was no mechanism in place to allow United States officials to transfer Medjuck over to Canadian authorities at the Canadian border."); McKeeve, 131 F3d at 7 (explaining that British authorities refused to accept custody of the defendant and "the U.S. Marshals Service lacks jurisdiction to retain custody of federal detainees on foreign soil"); Mueller, 74 F3d at 1156-57 (finding a deposition taken in England constitutionally admissible despite the defendant's involuntary absence); United States $v$ Kelly, 892 F2d 255, 260-63 (3d Cir 1989) (explaining that Belgian authorities "forbade the incarcerated defendants" to attend witness depositions); Salim, 855 F2d at 949-50 (describing how France prohibited the defendant from attending the deposition); United States $v$ Cannistraro, 800 F Supp 30, 70-72 (D NJ 1992) (finding a deposition taken in the Cayman Islands constitutionally admissible despite the absence of the defendant, who did not waive his confrontation right).

177 See, for example, United States $v$ Walker, 1 F3d 423, 428-29 (6th Cir 1993) (explaining that the defendants did not travel to Japan to attend depositions because they reasonably feared incarceration by Japanese authorities); United States $v$ Sines, 761 F2d 1434, 1441 (9th Cir 1985) (admitting deposition testimony taken without the presence of the defendant, who refused to travel to Thailand because he feared incarceration by Thai authorities).

178 See, for example, Nippon Paper, 17 F Supp 2d at 42. 
country, where there are concerns about the witness's reliability, or where there are concerns about difficulties with translation.

Furthermore, courts could allow video testimony where the prosecutor demonstrates in a motion that contemporaneous testimony is necessary to allow the presentation of important evidence and thorough cross-examination. Conceivably, the prosecution might convince a judge to allow video testimony after a Rule 15 deposition has already been taken in situations where the defendant has raised new defenses since the time of the deposition. ${ }^{180}$

Along the same lines, Rule 15 depositions might be foregone altogether if the court can anticipate the need for contemporaneous testimony. The prosecutor may reasonably anticipate a need for the foreign witness to discuss the testimony of other witnesses testifying at the trial. The prosecutor may even reasonably anticipate that the defense will raise issues, during direct or cross, that will require contemporaneous rebuttal testimony from the foreign witness. ${ }^{181}$ If the prosecutor can write a convincing pretrial motion demonstrating the need for contemporaneous testimony, the judge could make a sufficient case-specific finding that the videoconference testimony is necessary to further the public policy of providing reliable and relevant evidence at trial, as well as effective cross-examination by the defendant. ${ }^{182}$ In other words, given the constitutional considerations discussed in Part IV.C and the correspondingly lenient Craig analysis that should apply to video testimony when the only alternative is a Rule 15 deposition, there is no need for courts to insist upon the use of depositions in those cases where video testimony will provide significantly more

179 See id.

180 Note that this would still require a case-specific finding under the Craig test because the video testimony used at trial would not be given in the physical presence of the defendant.

181 Also, the contemporaneity of video testimony compared to deposition testimony may help the defendant cross-examine the witness more effectively in light of other testimony given at the trial, better serving the Confrontation Clause goal of effective and thorough crossexamination. This is another reason why courts should look favorably upon prosecution requests for allowing video testimony. See note 123 for an explanation of why the defendants in Yates and Gigante would not have acknowledged this benefit.

182 See Yates, 438 F3d at 1323 (Tjoflat dissenting) (arguing that judges should have discretion to determine that a deposition is not an adequate substitute for trial testimony and pointing out that the court could "consider the importance of the testimony being given in the context of the trial rather than months or years prior"). Consider Harrell v State, 709 S2d 1364, 1370 (Fla 1998) (citing the importance and relevance of the testimony as a public policy interest under the Craig test and stating that "there is an important state interest in resolving criminal matters in a manner which is both expeditious and just" and that foreign witness testimony may be necessary to serve that interest). This approach is consistent with the general principles of the Supreme Court's Confrontation Clause rulings. See Bourjaily, 483 US at 182 ("[W]e have attempted to harmonize the goal of the Clause-placing limits on the kind of evidence that may be received against a defendant - with a societal interest in accurate factfinding."). 
complete, more reliable, or more relevant cross-examination and testimonial evidence at trial.

In the situations described above, the extreme approach advocated in Yates would overemphasize the value of potential physical confrontation at a Rule 15 deposition while ignoring the other central elements of the Confrontation Clause. By looking only to whether a defendant will (or may) be physically present at a deposition in applying the Craig test to video testimony, Yates risks requiring Rule 15 depositions even in situations where the benefits of physical presence at a pretrial deposition are outweighed by the loss of a valid oath, effective cross-examination, or demeanor assessment by the finder of fact. For the reasons described in Part IV.C above, such an approach is not constitutionally necessary and is indeed inferior under the principles of Craig to video testimony in the above situations.

Finally, one potential criticism of this Comment's proposed solution should be addressed. Advocates of an expansive use of video testimony could argue that the proposal does not go far enough and that the principles and arguments that favor video testimony require that it be broadly approved in virtually all situations. Courts could formulate the equivalent of a per se rule that video testimony is constitutional by regularly making a "case-specific" finding that video testimony furthers an important public policy because it always allows reliable incourt testimony instead of the potentially less reliable out-of-court testimony that would be used under Rule $15 .{ }^{183}$ A court seeking to admit video testimony in all cases where a witness is unavailable could follow Yates in applying the Craig test but could disagree with Yates (and Justice Scalia) that Rule 15 depositions could ever provide a constitutionally superior means of securing witness testimony. ${ }^{184}$

These advocates may argue that the very nature of video testimony as at-trial testimony renders it superior to the out-of-court hearsay testimony provided by Rule 15 depositions. They might argue that the benefits of having the defendant physically present at a deposition are outweighed by the benefits of having the witness confront the judge and jury visually during videoconference testimony. They may also cite the problems that many defendants encounter in actually attending Rule 15 depositions and argue that since actual physical confrontation is not required for the admission of such depositions,

183 Yates, $438 \mathrm{~F} 3 \mathrm{~d}$ at 1323 (Tjoflat dissenting) (arguing that virtually all rulings approving video testimony are "unequivocally case-specific" and valid under Craig on the basis of the government's interest in providing reliable testimony).

184 See id at 1333-34 (Marcus dissenting) (arguing that Rule 15 depositions are never superior to video testimony in preserving Confrontation Clause rights). 
they do not actually offer defendants a reliable right to physically confront adverse witnesses.

However, given the number of possible case-specific findings discussed above and the wide range of foreign nations where defendants are likely to encounter serious obstacles to obtaining ideal Rule 15 depositions, it is almost certainly unnecessary to mount such a broad (and unlikely to succeed) attack on the general preference for physical confrontation embodied in Yates. Nor would such an approach comport with the framework of Craig or the well-established principles of the Court's Confrontation Clause cases of the last 150 years. Physical confrontation still has doctrinal significance after Craig, and videoconference testimony remains, for doctrinal purposes, an exception, albeit one that can be widely used.

Indeed, judges will likely be able to make case-specific findings that the use of video testimony instead of Rule 15 deposition testimony is necessary to further an important public policy in a wide variety of cases dealing with unavailable foreign witnesses, including virtually all cases where there is a significant reason for preferring video testimony. Courts can obtain the practical and functional benefits of videoconference testimony without deviating significantly from the Supreme Court's Confrontation Clause precedents.

\section{CONCLUSION}

Videoconference testimony is a recent phenomenon-one certainly not contemplated by the drafters of the Sixth Amendment-and its legal classification is unclear. The circuit split addressed in this Comment involves conflicting legal conceptions of video testimony and its ability to provide face-to-face confrontation under the Confrontation Clause. The Eleventh Circuit's application of the Craig test to video testimony offers the best fit with the Supreme Court's Confrontation Clause jurisprudence and the Court's general constitutional preference for physical confrontation. Yet the Eleventh Circuit errs in treating the possibility of physical confrontation at a Rule 15 deposition as the constitutional equivalent to traditional physical confrontation at trial.

Instead, this Comment proposes that courts applying the Craig test to video testimony by foreign witnesses should balance the functional value of physical confrontation at a Rule 15 deposition against the important elements of the confrontation right that video testimony may serve in a given case. Specifically, courts should rule that video testimony is necessary to further an important public policy under Craig in the many situations where Rule 15 depositions will be constitutionally deficient or where contemporaneous testimony is necessary to provide reliable and crucial evidence at trial. 